\title{
El sueño de los héroes de Bioy Casares: la clase como destino ${ }^{1}$
}

\author{
Rosalba CAMPrA*
}

\section{Resumen:}

La palabra destino siempre parece ligada al género fantástico, pero en el momento en que el destino se presenta como una constricción social que encamina la vida y las acciones de los personajes por derroteros específicos se abre la posibilidad de leer El sueño de los héroes de Adolfo Bioy Casares en esa conjunción evasiva que es la intercepción del sueño y la vigilia, de lo fantástico y lo social. Esta novela expresa una visión fantástica del mundo, pero también habla de lo que no es fantástico: en esta obra, lo no natural se entreteje con lo cotidiano de manera que un aspecto ilumina al otro y acaba por darle su razón de ser. El hecho fantástico constituye siempre el eje de la narración, pero no la agota, de modo que este trabajo propone una lectura que, abarcando lo fantástico, lo rebasa y, de esa manera, concluye que la novela es una alegoría de los mecanismos sociales.

Palabras clave:

Bioy Casares, El sueño de los héroes, fantástico, destino heroico, sueño y vigilia.

\section{La caracterización fantástica}

La narración fantástica, como sugieren innumerables ejemplos, parece encontrar su expresión más cumplida en la dimensión del cuento.

${ }^{1}$ Originalmente: "El sueño de los héroes di Bioy Casares: la classe come destino", en Annali dell'1stituto Universitario Orientale (Nápoles), Sezione Romanza, 22.2 (1980): 293-315. Traducción de José Miguel Sardiñas, revisada por la autora.

* Università di Roma La Sapienza. 
En éste, el suceso fantástico representa la totalidad, o casi la totalidad, de la estructura; es a la vez causa y meta del acto de narrar: en la manifestación del acontecimiento fantástico la narración se agota. En la novela, por el contrario, este tipo de sucesos sufre una notable expansión, o bien forma parte de una trama más amplia de significados.

Es lo que ocurre en la novela de Bioy Casares El sueño de los béroes. ${ }^{2} \mathrm{El}$ autor parece haber elegido el género fantástico tanto para expresar una visión fantástica del mundo como para hablar de lo que, en el mundo, no es fantástico: lo no natural se entreteje con lo cotidiano de manera que un aspecto ilumina al otro y acaba por darle su razón última. El hecho fantástico constituye siempre el eje de la narración, pero no la agota, de modo que se puede proponer para El sueño de los héroes -y ése es el fin de este trabajo- una lectura que, abarcando lo fantástico, lo trascienda y ponga de relieve lo que en la novela es secreta alegoría de los mecanismos sociales.

La caracterización fantástica de la novela es directa: antes de que la acción comience, el narrador define inequívocamente la naturaleza de los hechos, con lo que impone al lector una estrategia de lectura en una dirección única. Es como si dijera: atención, lo que sigue pertenece al género fantástico y en esta perspectiva debe ser leído:

A lo largo de tres días y de tres noches del carnaval de 1927 la vida de Emilio Gauna logró su primera y misteriosa culminación. Que alguien haya previsto el terrible término acordado y, desde lejos, haya alterado el fluir de los acontecimientos, es un punto difícil de resolver. Por cierto, una solución que señalara a un oscuro demiurgo como autor de los hechos que la pobre y presurosa inteligencia humana vagamente atribuye al destino, más que una luz nueva añadiría un problema nuevo. (7)

${ }^{2}$ Adolfo Bioy Casares, El sueño de los héroes, Buenos Aires: Losada, 1954. Para las citas se sigue la edición de Alianza Editorial (Madrid, 1976). 
La narración que sigue a estas palabras, sin embargo, no parece presentar elementos de naturaleza fantástica indiscutible, por lo cual, llegado el momento, el narrador, para evitar deserciones en el tipo de lectura que ha pedido, se apresura a advertir: "Ahora empieza la parte mágica de este relato, o tal vez todo él fuera mágico y sólo nosotros no hayamos advertido su verdadera naturaleza. El tono de Buenos Aires, descreído y vulgar, tal vez nos engañó” (161).

Pero no es solamente el narrador quien propone esta caracterización de los hechos. En mayor o menor medida, con un conocimiento más o menos declarado, también los personajes consideran que la aventura que les ha tocado en suerte vivir no se inscribe en el orden natural. En la certidumbre de lo cotidiano, se crea una pavorosa zona de sombra: “... Clara se preguntó si estaría entrando en una sala mágica, donde la tercera noche del carnaval de 1927 iba a repetirse" (168).

Abundan, así, términos como "mágico", "sobrenatural”, que dirigen unívocamente la interpretación del texto (véase: "situación mágica", "un mundo mágico" [164]; "circunstancias [...] inexplicables o, por lo menos, mágicas" [178]; "la explicación hubiera parecido fantástica" [166], etc.).

Ahora bien, podemos preguntarnos si, más allá de todas las indicaciones que proponen o imponen el sentido fantástico de los acontecimientos, éstos pueden sostener, por sí mismos, tal calificación. Los hechos son los siguientes: Emilio Gauna, un joven de la periferia de Buenos Aires, gana en las carreras una discreta suma. Decide gastarla en parrandas durante las tres noches de carnaval, e invita a los amigos del barrio, entre los cuales se distingue cierto doctor Valerga, jefe indiscutible del grupo. Quizá por la borrachera, el recuerdo de las noches de ese carnaval se desdibuja, y Gauna conserva sólo la imagen del encuentro con una joven disfrazada de dominó en una sala de baile. Ninguno de los del grupo puede, o quiere, darle una explicación, pero Gauna siente que algo maravilloso debe haber ocurrido. Un vidente, el Brujo Taboada, le aconseja que no intente revivir aquellas noches, pues algo que él ha impedido entonces podría suceder si Gauna insiste. Gauna se casa con Clara, la hija de Taboada - conocida en ocasión de una visita al vidente- y 
aunque a veces se siente atenazado por el recuerdo de aquel carnaval, bajo el influjo de Clara y de Taboada se aleja de sus viejos amigos. Así pasan tres años de vida serena y sin imprevistos. Pero Taboada muere y Gauna vuelve a frecuentar el grupo, a pensar con obstinación en su misteriosa aventura. La víspera del carnaval apuesta de nuevo en las carreras y de nuevo gana. Esto le parece un signo del destino y decide repetir, con los mismos amigos, el itinerario de tres años atrás. El pasado que poco a poco aflora en su memoria se manifiesta muy diferente de la maravilla que anhelaba: Gauna recuerda gestos de inútil crueldad de parte de Valerga y del grupo, a los cuales había asistido entonces pasivamente. Por fin, en el baile reencuentra a la máscara, y ésta le revela su identidad: es Clara. Gauna experimenta una especie de iluminación, pero en el baile pierde a su compañera, y esta vez nadie puede evitar, como había ocurrido tres años antes, que se cumpla el destino: en un duelo absurdo, Gauna muere por mano de Valerga.

Aun en una exposición rápida como ésta resulta evidente la ubicación de El sueño de los héroes en el ámbito de los temas fantásticos: se trata de una narración centrada explícitamente en la abolición de la direccionalidad temporal. El tiempo ha perdido aquí su carácter irreversible, como la misma Clara indica: "Clara supo que los temores se habían confirmado: desde algún instante imposible de precisar, el tiempo de ahora había confluido con el del 27" (173).

El tiempo de El sueño de los héroes es, como el de tantos cuentos y novelas fantásticas, un tiempo circular: los hechos del 27, que por una causa misteriosa en aquella fecha no llegaron a verificarse, emergen tres años después, logrando su cumplimiento; el cual es, a pesar de todo, una repetición (véase la ya citada "primera y misteriosa culminación" [7]), puesto que de alguna manera -inconclusa, imperfecta, sin consecuencia aparente- la acción está ya definida: pasado y futuro son intercambiables. Y así, Gauna refiere como un confuso recuerdo de la última noche del carnaval del 27 algo que en realidad debe todavía ocurrir:

Acepté la propuesta de dar una vuelta por los lagos; me levanté, dejé sobre la mesa la plata que debíamos y salí con 
Valerga y los muchachos. Después hubo una disputa. La veo como en un sueño. Antúnez o algún otro afirmó que yo había ganado en las carreras más que lo que dije. En este punto, todo se vuelve confuso y disparatado, como en los sueños. Yo debí de cometer una terrible equivocación. Según mis recuerdos, el doctor se puso de parte de Antúnez y acabamos peleando a cuchillo, a la luz de la luna. (118)

Se crea pues, de este modo, una transgresión no explícita de las fronteras entre la vida y la muerte: Gauna es alguien cuya muerte solamente ha sido suspendida. Para él, llegará en el 30, pero en el plan trazado por el destino, todo ha concluido ya.

\section{Los testimonios del suceso fantástico}

Las cosas no son, sin embargo, tan cristalinas como pueden parecer. ¿Qué seguridad se ofrece al lector de cuanto ha sucedido? Se manifiesta aquí otro de los problemas a menudo presentes en el universo fantástico: la duda en torno a la realidad efectiva de los acontecimientos. Esta garantía de verdad no puede proceder de Gauna: el protagonista del suceso fantástico, en cuanto tal, no está en condiciones de aportar un testimonio objetivo; su palabra no tiene valor probatorio. Es Taboada quien afirma la colocación de los hechos más allá de la causalidad natural. En tres ocasiones, "el Brujo" se adjudica la capacidad de modificar la trama de la vida de Gauna: "Yo lo defendí contra un Dios ciego, yo rompí el tejido que debía formarse. Aunque sea más delgado que hecho de aire, volverá a formarse cuando no esté yo para evitarlo" (37; véanse, también, 96 y 113).

Pero tampoco estas palabras se pueden considerar probatorias en sí: son una declaración de Taboada sobre la presunta responsabilidad de Taboada mismo en los hechos. Aparecen, pues, como un testimonio interesado. Más consistente puede considerarse, en este sentido, la función de Clara. Ella ha participado tanto en el carnaval del 27 como en el del 30, y su testimonio prueba que los hechos 
que Gauna recuerda como ocurridos en el 27 pertenecen en realidad a un tiempo posterior. Ésta es de hecho la motivación que Clara alega para pedir ayuda a un amigo suyo, el rubio, que ya la había acompañado durante el primer carnaval:

-Escúcheme, por favor. Me dijo que él estaba solo en una mesa y que me vio en el bar y que yo le sonreí a usted y que a él le dio rabia y que se fue con sus amigos. Bueno, eso no pasó la otra vez; comprende: nada de eso pasó la otra vez; pasó hoy, todo, tal como él me lo dijo [...]. Vio lo que debió ocurrir la otra vez, lo que está ocurriendo ahora [...]. Si no lo impedimos, Valerga lo matará. (177)

Estas palabras de Clara, si bien prueban la existencia de un salto temporal, la prueban, de todos modos, por medio de Gauna. Es sólo el recuerdo de Gauna lo que establece la certeza de la muerte en el carnaval del 30. Se podría entonces hablar de premonición, como cuando él, en una pausa del carnaval del 30, sueña estar luchando a cuchillo con Valerga bajo la luz de la luna (137). Aunque quede sin aclarar el papel de Taboada en los hechos del 27, los límites de lo fantástico en El sueño de los héroes parecerían restringirse a los de un fenómeno parapsicológico. En efecto, esto es lo que Clara intuye: "De acuerdo a lo previsto, el destino había tomado a su cargo la situación. Mientras pensaba en eso, intuyó que era falso; intuyó, tal vez, que el mundo no es tan extraño; mejor dicho, tiene su manera de ser extraño, fortuita o circunstanciada, pero nunca sobrenatural" (172).

En el "tal vez" introducido en el discurso indirecto que transmite el pensamiento de Clara descubrimos la presencia de otro testigo, situado en un nivel textual diferente: el narrador. Como hemos visto, una primera función del narrador ha sido la de dirigir la lectura en sentido fantástico. Pero, ¿quién, o qué es este narrador? Si bien no se presenta como participante directo en los hechos, aparece caracterizado en modo personal, como un 'yo': "Para mí tengo que Gauna comprendía que si dejaba la aventura a mitad de camino, le quedaría un descontento hasta el día de la muerte" (147). 
Este 'yo' de alguna manera ha presenciado los acontecimientos, o los ha conocido, por lo cual se coloca en el mismo plano de los personajes, y del destinatario, quien, por medio de la apelación directa, queda también incluido en el mundo representado en la novela: "Y como alguno de ustedes acaso recordará, Calcedonia ganó, ese primero de marzo, la cuarta carrera" (122).

Según la habitual prerrogativa del narrador, el orden y la selección de los acontecimientos dependen de su arbitrio: "De la influencia de esta admiración sobre el destino de Gauna todavía no hablaremos" (8).

Esta posibilidad se deriva, en el caso específico de El sueño de los héroes, de la colocación del acto narrativo al final de los acontecimientos: la historia es narrada cuando todo ha concluido, como lo demuestran las numerosas anticipaciones temporales. Sin embargo, el poder de que dispone el narrador se desvanece cuando se trata de dar garantías acerca de la naturaleza fantástica de los hechos: dado que la voz que narra es la de una 'persona', un 'yo', todo su testimonio se tiñe de improbabilidad. ¿Cuál puede ser la veracidad de un narrador que, categorizado como personaje, parece por lo tanto ver tan sólo gestos y apariencias, mientras que otras veces, por el contrario, está en condiciones de revelar sueños, secretos pensamientos, emociones -aun cuando modere ese conocimiento injustificado con un "tal vez", un "quizá" (véanse: 15, 19, 109, 172, etc.)? Por otra parte, la focalización del narrador coincide, en lo que respecta al suceso fantástico, con la de Gauna, es decir con una visión limitada, por medio de la cual no se ofrecen al lector certezas, sino opiniones. Esta identificación con Gauna en el plano del conocimiento de los hechos no significa coincidencia con los valores del personaje: al contrario, con frecuencia el narrador emite juicios negativos sobre el mundo de Gauna y de los demás personajes, con lo que marca claramente una distancia, sobre todo a través de la ironía (como se verá más adelante). Sin embargo, en el último capítulo, que contiene la secuencia final del duelo y la muerte de Gauna, la distancia se ha borrado. Por primera vez el narrador se identifica totalmente con los valores de su personaje, de modo que en el momento de la confluencia de tiempos se ofrece al lector un testimonio 
único: la realidad vista a través de Gauna. Toda valoración ajena ha desaparecido; es Gauna quien se ve morir y quien se juzga. Su muerte es, pues, el terrible y luminoso cumplimiento de un destino, y él es el héroe de una aventura fantástica:

Vagamente sospechó ya haber estado en ese lugar, a esa hora, en esa abra, entre esos árboles cuyas formas eran tan grandes en la noche; ya haber vivido ese momento. Supo, o meramente sintió, que retomaba por fin su destino y que su destino estaba cumpliéndose. También eso lo conformó. No sólo vio su coraje, que se reflejaba con la luna en el cuchillito sereno; vio el gran final, la muerte esplendorosa. (178)

\section{Lo fantástico en el discurso}

Los reparos sobre la explicación fantástica de los acontecimientos se expresan también en el nivel verbal: por una parte los mecanismos del discurso la afirman, por otra materializan una ambigüedad sustancial. A favor de esta última obran las frecuentes modalizaciones del tipo "lo que Gauna creía recordar" (20, subrayado mío). El recuerdo de lo sucedido después del encuentro con la máscara la última noche del carnaval es presentado por medio de la estructura verbal del sueño, es decir el imperfecto: "La máscara había desaparecido. El preguntaba por ella; no le contestaban o procuraban calmarlo con evasivas, como si estuviera enfermo. No estaba enfermo. Estaba cansado" (23).

Sin embargo, en esta trama uniforme que da a los acontecimientos la connotación de una evanescencia se introduce, sin transiciones, un tiempo de la realidad: el duelo con Valerga se relata en pretérito indefinido. ¿Simple cambio verbal, o bien indicio de un acontecer real? "Se encontró luego entre árboles, rodeado por gente, atento al inestable y mercurial reflejo de la luna en su cuchillo, inspirado, peleando con Valerga por cuestiones de dinero" (23).

Gracias a este juego de certidumbres alternativamente confirmadas y desmentidas se crea una indicialidad difusa de la narración. 
Todo elemento, incluso el más irrelevante, va cargándose de significados ocultos, remite a algo más allá, se propone como espacio de un desciframiento que el lector debe completar para descubrir en cada aspecto de lo cotidiano la huella invisible de lo fantástico. Indicios en sentido propio son, por una parte, todas las pistas esparcidas a lo largo de la acción que puedan llevar al lector (también a Gauna, si estuviera en condiciones de prestar atención a su propia realidad) a identificar en Clara a la máscara del baile. Los acompañantes de la muchacha enmascarada y los jóvenes del automóvil que van a buscar a Clara son descritos del mismo modo; en el velorio de Taboada, alguien que saluda a Clara despierta en Gauna una oscura reminiscencia. La identidad de los personajes se va precisando poco a poco: en el salón de baile, en el carnaval del 30, Gauna ve "a uno de los muchachos del Lincoln, al rubio cabezón que en 1927 apareció en el mismo local” (62). Después de indicaciones tan explícitas, con una sola frase el narrador muestra su juego y renuncia a las escenas de sorpresa y reconocimiento: "Con estas palabras se ha dicho que la máscara era Clara. La de esa noche y la que en 1927 lo deslumbró" (165).

$\mathrm{Al}$ mismo tipo de indicios pertenecen las alusiones al importe de la suma ganada por Gauna en las carreras, tanto en el 27 como en el 30: la acusación de haberse reservado una parte del dinero será la causa más o menos real del duelo con Valerga. En esta óptica se podrían analizar, en última instancia, todas las acciones de la novela: cada una de ellas se une más o menos directamente al punto de llegada -que es el mismo que el de partida.

Otro tipo de indicios, por su parte, otorga a la narración una connotación fantástica; por ejemplo, el hombre que, en la víspera del carnaval del 30, da a Gauna la indicación para las carreras aparece como mensajero de un destino funesto: "Un señor vestido de negro, con paraguas, con cara de pájaro de mal agüero" (121).

En otras ocasiones, la pista fantástica puede rastrearse en discursos que, como los de Taboada, proponen la existencia de un mundo cuyas leyes son incognoscibles. De todos modos, en la boca de un vidente las alusiones misteriosas pueden darse casi por descontadas. Otras palabras, en cambio, al parecer inocentes, en una 
lectura posterior se revelan cargadas de peligro. En el carnaval del 27 , por ejemplo, Gauna afirma que "el carnaval no dura una noche" (9), abriendo así, sin saberlo, la posibilidad de la reiteración temporal. La misma frase es pronunciada por Gauna en el carnaval del 30, un día antes del duelo, con una variante que le confiere un siniestro significado de conclusión: "El carnaval dura hasta mañana" (156).

Asimismo, las palabras del tango que Antúnez, uno de los amigos del grupo, ha canturreado varias veces, al ser pronunciadas como conclusión de la secuencia en que Gauna decide rehacer el itinerario del 27, se vuelven signo inequívoco de cuanto sucederá: “Contra el destino / nadie la talla" (125).

Este sentido negativo se impone igualmente cuando la palabra "destino" es usada en la acepción de 'punto de llegada'. Cuando Gauna, en el curso de un accidentado viaje hacia una casa en el campo, alude a la poco atractiva meta que los espera, es inevitable el desciframiento de la frase chistosa como referencia a la fatalidad que dirige su vida: "-No te acalores [...]; con el destino que llevamos, lo mejor es perderse” (81).

\section{Un itinerario en el pasado}

Encontrar, perder, volver a encontrar, perderse: tal es la parábola de la vida de Gauna. La confluencia de los dos tiempos se realiza a causa de su empecinado deseo de recuperar, por medio de la repetición del itinerario del 27, el recuerdo de un momento que se supone mágico, pero cuyo reencuentro significará la muerte. Así, pues, esta búsqueda adquiere la forma canónica del viaje, real y metafórico. El peregrinaje de Gauna por las calles de Buenos Aires deviene descenso hacia lo más profundo de sí mismo. Dos son los polos de esta búsqueda: el itinerario seguido en el carnaval del 27, que se ha cancelado de la memoria de Gauna, y el del 30, repetición y cumplimiento del primero en una circularidad perfecta. Desde el momento del despertar en el parque de Palermo, sabiendo que algo ha pasado pero sin lograr definir qué, una red de proyectos, fantasías y 
esfuerzos concretos se va entrelazando, tensada por momentos de renuncia, en un flujo y reflujo hacia el pasado. Las tentativas de Gauna por recuperar la memoria de aquellas noches se articulan en cuatro etapas: búsqueda por medio de una pesquisa, repetición parcial e inconsciente del itinerario, nueva pesquisa, repetición total y consciente. Las primeras tentativas se dirigen a interrogar a quienes lo han acompañado: el peluquero que le ha indicado el caballo ganador, los amigos del grupo. Pero el peluquero no lo recibe, luego desaparece definitivamente; los amigos actúan con una hostilidad mal disimulada. Taboada no sólo no le da ninguna información -aun demostrándole poseerla-, sino que, por el contrario, intenta disuadirlo de su búsqueda. Un episodio que duplica grotescamente el interrogatorio de Gauna a Taboada cierra esta primera etapa y abre la del peregrinaje involuntario. Gauna le pide la suerte a una cotorrita, y ésta le extiende un papel con palabras tan sibilinas como las de Taboada:

Los dioses, lo que busque y lo que pida, como loro informado le adelanto, ¡ay! le concederán. Y mientras tanto aproveche el banquete de la vida. (69) ${ }^{3}$

El efecto de la predicción del atrabiliario pájaro sobre Gauna es una súbita tristeza que lo lleva a vagabundear sin objetivo, hasta internarse en barrios desconocidos. Aquí la búsqueda se convierte en un deambular sonámbulo que el texto pone de manifiesto por medio de la acumulación obsesiva de verbos de movimiento y de la confusión entre espacios nombrables y otros de inquietante vaguedad:

Prosiguió con rumbo oeste [...]; avanzó interminablemente por calles desconocidas [...]; entró en un almacén [...]; volvió

${ }^{3}$ Otra vez un juego de reenvíos: en su visita al vidente, Gauna dice que se dirige a él con el mismo desinterés de quien interroga sobre su futuro "al loro que da la papeleta verde" (37). 
a caminar; se encontró en una avenida que era Triunvirato y dobló a la izquierda [...]. Caminó un tiempo que podía ser la eternidad; bordeó el paredón del cementerio de la Chacarita; cruzó vías [...], pasó por corralones y [...] avanzó por fin por la calle Artigas [...]. Cruzó otras vías, llegó a la plaza de Flores. (70-71)

Este divagar concluye en un tranvía - previsible imagen del destino- que conduce a Gauna hacia los sitios ya visitados en 1927. Sin que ninguna palabra en particular lo aclare, por la descripción se deduce que Gauna ha entrado en un burdel. La dueña es una señora "con tosco acento extranjero" (73); un violinista de aspecto melancólico huye aterrorizado al oír la voz de Gauna. Pero éste no está preparado todavía para el descubrimiento; todo parece ocurrir más allá de su conciencia. Sin preguntarse el significado de la acción del músico, del silencio repentino de los demás, se aleja. Después de un largo período de renuncia, la enfermedad y la muerte de Taboada le abren a Gauna una nueva etapa de búsquedas. Primero, interroga sin éxito a los dos hombres que lo recogieron en el parque tras su aventura, después empieza a frecuentar de modo casi obsesivo a las mujeres de los establecimientos nocturnos, esperando inútilmente que alguna lo ayude a reconstruir el pasado perdido. El premio en las carreras crea la posibilidad -que Gauna siente como obligatoria- de repetir el itinerario del 27 en las mismas condiciones de entonces. La peregrinación por los lugares de la memoria cierra para siempre la aventura de Gauna: todo encuentra su justificación y su terrible sentido. Como tres años antes, a la invitación de Gauna Valerga contesta: “-Ya te dije, muchacho [...], que no soy un circo, para tener compañía” (126).

Ese "ya" pone sutilmente en la misma línea temporal, aboliendo toda distancia, el carnaval de 1927 y el de 1930. La recuperación de la memoria se marca por medio de la reiteración temporal en espacios que coinciden exactamente. Así, "el establecimiento de las alemanas" -en el cual el lector reconocerá el burdel de la señora con acento extranjero- ahora cerrado, no despierta en Gauna ninguna reacción. En cambio, al entrar a cierto café, al recorrer ciertas 
calles, el pasado se asoma débilmente a su memoria -la imagen de un niño, de un caballo, de una quinta. Pero a las peticiones de aclaración, el grupo opone el silencio. A instancias de Gauna, todos se dirigen a la quinta, adonde llegan en medio de la oscuridad. Las imágenes emergen entonces repentinas y completas: un niño perdido entre las máscaras del carnaval pide ayuda, y Valerga, fingiendo acompañarlo, lo abandona en un tranvía con destino desconocido; un violinista ciego -en quien Gauna después identificará al hombre que había huido al oír su voz- es golpeado brutalmente por Valerga. Finalmente, en la claridad del alba, Gauna descubre que la "quinta" es una barraca en un basural y recuerda la escena de un caballo torturado por el grupo hasta que él mismo, para evitar más atrocidades, lo mata con un disparo. La maravillosa aventura de las noches de carnaval se ha revelado, pues, como algo abominable, como una grotesca manifestación del mal, y Gauna quisiera regresar junto a Clara. Pero ya es demasiado tarde: “... muy pronto se aburrió de esa actitud enérgica, lo invadió la indolencia y con una suerte de júbilo sutil y secreto se abandonó a lo que el destino quisiera" (147).

\section{La meta final}

Cada una de las estaciones de esta peregrinación última marca, pues, una etapa más profunda del conocimiento. Todo el resto se vuelve preparación o imagen de este viaje definitivo: el deambular por las calles de Buenos Aires, los vagos deseos de evasión, hasta una absurda excursión al campo (la visita a Chorén [78-86]), desdoblan, en un registro grotesco, la estructura de la búsqueda. Como todo viaje verdadero, el de Gauna es aprendizaje de sí; como todo viaje verdadero, en su meta encierra una revelación. La meta final parece ser aquí el pasado, revivido por obra de la memoria: “... penetrar de nuevo las visiones que había recibido y perdido esa noche, y alcanzar definitivamente lo que fue, como en el éxtasis de un sueño olvidado, la coronación de su vida" (122).

El contenido de este pasado, lo que Gauna busca en primer lugar, es la máscara. Lo afirma así Valerga, concluyendo malignamente: 
"En ocasiones queremos volver a los lugares que en la dorada juventud hemos frecuentado. En ocasiones, he dicho, porque ni el más hombre está libre de acordarse de alguna mujer [...]. Hacés bien de no hablar. Estos hombrecitos de ahora cuentan todo y ni siquiera respetan el buen nombre de la arrastrada que les hizo caso" (134).

$\mathrm{Y}$ así parece ocurrir también con Gauna, puesto que la primera pregunta que le hace al vidente es si volverá a ver a la máscara. Pero el mismo Gauna tiene conciencia de que esa centralidad es sólo un aspecto de un problema mucho más complejo: "Lo más extraño de todo esto es que en el centro de la obsesión de Gauna estaba la aventura de los lagos y que para él la máscara era sólo una parte de esa aventura, una parte muy emotiva y muy nostálgica, pero no esencial" (26).

Se crea, de esta forma, una superposición de objetos, un juego de desfasamientos en el cual el primer objeto resulta nada más que una apariencia. Gauna busca el encuentro con la máscara pero este encuentro, sin él saberlo, ya ha tenido lugar. El descubrimiento será, pues, la identificación de la máscara con Clara, de la aventura fabulosa con la cotidianidad: "Tal vez yo imaginé dos amores. Ahora veo que hubo uno solo en mi vida" (170).

La expectativa se satisface, así, de modo completo: la revelación de la identidad de la máscara desconocida deviene revaloración de la compañera de la vida. ¿Por qué entonces la historia va más allá? A través del reiterado motivo literario del reconocimiento de una máscara se expanden aquí otros significados. En la última estación del viaje, lo que espera no es el amor, sino la muerte, no el pasado sino un presente fatal. El objeto encontrado no parece coincidir con aquél que se buscaba. Ahora bien, ¿qué es esta muerte para Gauna, sino el cumplimiento de su destino y la revelación de su identidad? La meta verdadera, que Gauna ignora estar buscando, es el conocimiento de sí, que sólo en la muerte es completo e indiscutible, porque se cristaliza en una imagen definitiva, sin posibilidad de cambios. En este juego de desfasamientos se descubre poco a poco como objeto final de la búsqueda la confirmación, para el personaje, de una imagen de sí mismo. La historia de Gauna 
no es la del héroe de la confluencia fantástica de dos tiempos, o no es sólo ésa. Se trata, más bien, de la víctima de una constricción personal y social a producir una imagen de sí admisible para sí mismo y para el grupo.

Ya desde el comienzo se marca el desnivel entre lo que Gauna quiere ser y lo que la realidad le permite. Sus aspiraciones de "vivir por su cuenta y no deber favores a nadie" (8) quedan desmentidas apenas expresadas: a Gauna los problemas se los resuelve Larsen, que le encuentra trabajo en un taller, y a continuación ambos comparten un cuarto alquilado. Este detalle, insignificante en una primera lectura, es, sin embargo, la primera pista de la constante frustración de la propia imagen que Gauna sufre. Huérfano, provinciano, Gauna es una persona que no pertenece ni al lugar ni al ambiente social en que le toca vivir. Inseguro de su identidad, siente que sólo el grupo puede conferírsela, por lo que trata de adaptarse a lo que los demás esperan -o Gauna supone que esperan- de él. Su drama no es el de ser diferente, sino el de no querer serlo. Sus actitudes demuestran la necesidad de integración a los valores del grupo, en cualquier plano: como los demás se aburren con los cuentos del patrón del taller, Gauna, que en realidad se siente interesado, "simulaba aburrirse" (10). Sólo la pertenencia al grupo da un sentido a la existencia, pero la adhesión no siempre se produce sin dificultad. Por un lado, porque el grupo tiende a rechazarlo, y a veces no lo oculta; por otro, porque la naturaleza de Gauna contrasta con lo que él se ha impuesto, y sus gestos a menudo desmienten sus declaraciones. Por ejemplo, la imagen de la mujer según el grupo, y por ende según Gauna, es totalmente negativa, y se resume en una serie de lugares comunes: "Lo alejan a uno de los amigos [...]. Lo ablandan a uno" (54); "...las mujeres lo corrompen a uno con sus cuidados y delicadezas" (57); "Las mujeres le cortan a uno las alas" (91).

Puesto que no se puede prescindir de ellas, las mujeres deben por lo menos responder a un ideal particular de belleza: "Las

${ }^{4} \mathrm{Y}$ sus sentencias se confirman puntualmente: el encuentro con Clara transforma la vida de Gauna, alejándolo de los amigos, de la necesidad de aventura, de lo que -de acuerdo con los códigos del grupo-define al hombre (véase nota 5). 
muchachas debían ser rubias, con algo estatuario en el porte [...], con la piel dorada y los ojos grises o, por lo menos, azules" (86).

Ni éstas ni otras declaraciones explícitas de Gauna se ajustan a sus sentimientos: "Clara era delgada, morocha, con esa frente prominente, que él aborrecía. Desde el principio la quiso" (86).

Así, si las palabras de Gauna expresan desprecio, desconfianza hacia la mujer, la experiencia de sus relaciones con Clara es muy otra: respeto, ternura, inclusive admiración. Un desnivel parecido puede hallarse, en sentido contrario, en el plano de la amistad, culto esencialmente viril, que Gauna profesa incondicionalmente hacia Larsen: "Gauna recordó otras noches, en otros barrios, en que también, a la luz de la luna, habían orinado juntos; pensó que una amistad como la de ellos era la mayor dulzura para la vida del hombre" (16).

Pero, de parte de Larsen, en la acción poco hay, más allá de esta clase de gestos, que justifique tales pensamientos: personaje de una prudencia que roza la cobardía, egoísta, indiferente, Larsen rehúsa acompañar a su amigo tanto en el 27 como en el 30, aun sabiendo que la segunda vez Gauna va al encuentro de un peligro, y se niega a ayudar a la desesperada Clara. Como una defensa anticipada, el narrador asevera: "Algunas personas encontrarán incomprensible esta cobardía, pero nadie debe dudar de la amistad de Larsen por Clara y Gauna. Hay sentimientos que no precisan de actos que los confirmen y diríase que la amistad es uno de ellos" (166).

Sin embargo, en la constelación de valores de Gauna, amor y amistad son elementos secundarios. Todo se centra en un valor único, absoluto, que constituye la definición del hombre: el coraje. ${ }^{5}$ En este plano, Gauna aparece marcado por su experiencia infantil. Recuerda actos de su infancia en los que demostró falta de coraje, y que tuvieron a Larsen como espectador - una vez cruzó la calle para no pelear con un chico, otra se negó a luchar con un amigo que

${ }^{5}$ El tema del coraje explica la presencia de secuencias no relacionadas directamente con la acción. En las ridículas aventuras amorosas del peluquero Pracánico, amenazado por un marido ofendido, hay, en otro nivel (como se ha notado para el viaje a la casa de Chorén, duplicación grotesca de la búsqueda de los lugares del pasado), un reflejo de las obsesiones de Gauna, quien significativamente no manifiesta ninguna 
lo había traicionado. Larsen, por su parte, recuerda otros hechos, en los que Gauna aparece como "la imagen del valor" (15)- aleja a un perro rabioso, pone en fuga a unos ladrones con una estratagema. No importa tanto, pues, la imagen que los demás tienen de Gauna como la que él piensa que tienen; en última instancia, la imagen que Gauna tiene de sí. Para poder modificarla, Gauna tendría que poner a prueba su coraje con una acción individual:

Ahora no tenía fama de cobarde. Vivía entre aspirantes a guapo y no tenía fama de achicarse. Pero es verdad que ahora casi todas las peleas se resolvían con palabras; en el fútbol hubo algunos incidentes; asunto de tirarse botellas o pedradas o de pelear indiscriminadamente, en montón. Ahora el valor era cuestión de aplomo. Cuando uno era chico uno se ponía a prueba. Para él, el resultado de la prueba había sido que era cobarde. (15)

Así pues, Gauna sobrelleva la marca infamante de aquella experiencia infantil no desmentida. Pero si bien busca un acto que confirme su coraje, rechaza sin motivo aparente las ocasiones que se le presentan. La primera oportunidad desaprovechada tiene lugar en el baile, cuando los acompañantes de la máscara lo provocan: “...quién es usted para robarnos la máscara", y antes de acabar de hablar se puso en guardia, como boxeador. Gauna palpó su cuchillito, en el cinto. Aquello fue como una pelea de perros: los dos se distrajeron muy pronto" (23).

Otra ocasión, rápidamente descartada, nace de los celos que le provoca Baumgarten, un pretendiente de Clara: "Otra idea sería esperar a ese chancho en un baldío y provocarlo. 'Si quiere trompadas, lo beneficio con el cuchillito hasta el mango de anta'...” (68).

reacción ante la orgullosa declaración de cobardía del peluquero: "Yo no sirvo para hacer frente a situaciones difíciles. Se lo juro por lo que más quiera: yo soy un cobarde infame" (120). 
La contradicción se explica, en cambio, si se tiene en cuenta que, en ninguno de estos casos, el choque puede funcionar como prueba: los contendientes no se hallan en el mismo nivel de Gauna, por ser otro el origen social y otra la actitud ante la lucha -al cuchillo oponen los puños. No pueden, pues, merecer sino su desprecio. Por otra parte, incluso la motivación es contingente: una mujer. De modo que la primera posibilidad real de afirmarse como hombre se presenta sólo cuando Gauna se encuentra cara a cara con Valerga. El adversario es alguien que goza de toda su admiración; es de su misma clase; el encuentro es un duelo con el arma por excelencia de los hombres, el cuchillo. Y, en fin, el único motivo real de la lucha es la demostración del coraje. La muerte, para tener un sentido, debe ser gratuita:

En un abra del bosque, rodeado por los muchachos, como por un cerco de perros hostiles, enfrentado por el cuchillo de Valerga, era feliz. Nunca se había figurado que su alma fuera tan grande ni que en el mundo hubiera tanto coraje [...]. Don Serafín Taboada le había dicho una vez que el coraje no era todo; don Serafín Taboada sabía mucho y él poco, pero él sabía que es una desventura sospechar que uno es cobarde. Y ahora sabía que era valiente. Sabía también que nunca se había equivocado sobre Valerga: era valiente en la pelea. Vencerlo a cuchillo iba a ser difícil. No importaba por qué estaban peleando. (178)

\section{Los modelos del héroe}

Esta última escena ilumina también el sentido de las dos figuras que a lo largo de la historia se disputan la admiración de Gauna: Valerga y Taboada. En la imagen de sí que el sujeto construye, la parte fundamental está representada por estos personajes, los dos polos posibles de la identificación. Ya que, en realidad, Gauna no está en busca de sí mismo, de una identidad libre de las circunstancias, sino de un modelo, de una imagen a la cual adecuarse. La 
lucha de Gauna no es por ser, sino por semejar. Demasiado elemental sería decir que uno de estos polos representa el mal (Valerga) y el otro el bien (Taboada), pero es cierto que cada uno aparece como portador de valores contrapuestos. Y entre Valerga y Taboada oscila Gauna, en el complejo juego de las posibilidades connaturales al hombre y que el ambiente definirá: “... él mismo comprendía que podía ser valiente o cobarde, generoso o retraído, que todavía su alma dependía de resoluciones y de azares, que todavía no era nada" (79).

Valerga es "maestro y modelo" (50); en cualquier asunto -caballos, política, coraje- su palabra es ley. Sin embargo, las razones por las que el barrio lo ha transformado en un mito no son evidentes. Su fama se deriva, íntegra, del pasado, por lo que sus actos de coraje existen sólo en la palabra. Mas todo encuentra explicación en la decadencia de las costumbres, que no permiten al hombre demostrar que lo es: “... en los tiempos actuales, el inevitable destino de los valientes era rememorar hazañas pretéritas” (14).

Sin embargo, cuando cuenta alguna de esas 'proezas', de bien poca cosa se trata: cortar con el filo de una carta al compañero que trampeaba en el juego, prender fuego a una máscara que le ha hecho un desaire. Y cuando finalmente el propio Gauna presencia las acciones de Valerga, éstas son crueldades contra víctimas indefensas: un niño perdido, un caballo moribundo, un ciego. Así, Gauna descubre en Valerga la imagen negativa y carente de grandeza que Taboada le había pronosticado. Quizá por influencia del mismo Taboada, Gauna empieza a advertir en Valerga inclusive rasgos de vulgaridad en la forma de hablar (a menos que, como veremos después, estas indicaciones deban atribuirse más bien a la posición del narrador): "-No me parece atinada la observación -dijo el doctor[...] omitiendo, en la última palabra, la letra "b"” (99).

De cualquier manera, como en el caso de la amistad, tampoco el coraje precisa sustentarse en actos: es una esencia. Sólo Gauna necesita demostraciones para probarse a sí mismo. La admiración por Valerga, en cambio, si bien resquebrajada por momentos, se recrea independientemente de sus acciones: 
Olvidando los rencores, Gauna lo miró con la prístina admiración intacta, deseando creer en el héroe y en su mitología, esperanzado de que la realidad, sensible a sus íntimos y fervorosos deseos, le deparara por fin el episodio, no indispensable para la fe, pero grato y atestiguador -como para otros creyentes, el milagro-, el resplandeciente episodio que lo confirmase en su primera vocación y que le devolviese, después de tantas contradicciones, la venia para creer en la romántica y feliz jerarquía que pone por encima de todas las virtudes el coraje. (155)

Ante esta imagen de hombre perfecto propuesta por Valerga, se alza el modesto pero absoluto desafío de Taboada. Otros son los valores que éste encarna y que quiere transmitir a Gauna. Si Valerga es "el doctor", Taboada es "el Brujo". Ya desde estos títulos más o menos irónicos se oponen dos saberes de diversa naturaleza. Inclusive desde el punto de vista de la trama, cada uno recibe un tratamiento diferente. Valerga aparece en la primera página, a través de una descripción particularizada, en tanto que Taboada emerge poco a poco, a través de indicaciones dispersas que crean un aura de misterio a su alrededor. La reacción de Gauna cuando se encuentra por primera vez con Taboada es de desconfianza, casi de desprecio, que llega a la hostilidad en el momento en que éste se permite criticar a Valerga. Pero el tiempo demuestra gradualmente a Gauna que el mundo que Taboada representa contiene valores a los que él no ha tenido acceso hasta entonces: "En las palabras del Brujo entreveía un mundo desconocido, quizá más cautivante que el valeroso y nostálgico del doctor" (36).

Sobre todo, Taboada representa otra concepción del coraje. Para él, el coraje consiste no tanto en combatir como en saber renunciar a la pelea, en el dominio de sí, en abandonar el egoísmo de la aventura. Y no sólo esto. Taboada encarna (naturalmente, en la medida del personaje) el mundo de la cultura: gracias a él, Gauna comienza a interesarse por la lectura, por las ciencias. En este sentido, la función de Clara duplica la de su padre: de objeto se convierte en ayudante, al proponerle a Gauna, también ella, los valores de lo 
cotidiano, de la felicidad doméstica, de la elevación cultural -por más reducida que ésta sea-, o al actuar como obstáculo frente a la identificación de Gauna con Valerga. ${ }^{6}$ Sin embargo, Taboada es, al fin de cuentas, la otra cara de Valerga. Aunque opuestos, ambos desarrollan la misma función de modelo para imitar. Gauna, de hecho, percibe esta identidad de funciones: "Lo más raro de todo es que por momentos yo encontré que el doctor Valerga se parecía al brujo Taboada" (53).

$\mathrm{Si}$ entre estas fuerzas equivalentes una vence a la otra, es porque la muerte de Taboada, eludiendo la lucha, lo simplifica todo. La imagen de Valerga resulta victoriosa sobre una ausencia, como afirma el narrador: "Sin embargo, yo sigo creyendo que la suerte de Gauna y de Clara sería otra si el Brujo no hubiese muerto" (116).

Es decir, que lo único atribuible al destino es en realidad el hecho de haber privado a Gauna de la posibilidad de elegir. Con la desaparición de Taboada, sólo una imagen permanece, la de Valerga. Ambos personajes, pues, no aparecen como alegorías del bien y del mal, sino como figuras metafóricas de una sola cosa, la constricción de ser. Y es ése el sentido del destino en El sueño de los héroes: la imagen de sí que Gauna se ve obligado a elegir como meta.

\section{7. ¿Qué predestinación?}

Con esta óptica pueden descifrarse las numerosas alusiones al destino que el texto ofrece. Una primera acepción, la más difundida, es

${ }^{6}$ Desde esta perspectiva, la función de la joven plantea problemas de otro orden. Por lo que respecta a la acción, Clara obra como la endormeuse d'énergie de las novelas caballerescas; es quien retiene al hombre en su carrera hacia la aventura y, encerrándolo en el estrecho horizonte de la felicidad doméstica, se interpone entre él y su destino. Pero si el resultado del conocimiento es la muerte, ¿es mejor entonces no saber, como afirma Taboada, y como tienden a demostrar las acciones de Clara? Como quiera, el único obstáculo verdadero para el cumplimiento del destino es la presencia de Taboada; la mujer no puede constituir un modelo. Y, de hecho, las palabras finales de la novela la relegan en un mundo sin significación: "Infiel, a la manera de los hombres, no tuvo un pensamiento para Clara, su amada, antes de morir" (178). 
la de fatalidad impersonal, de ciega concatenación de hechos que determina la vida de los hombres. El destino es un poder al cual resulta imposible, y sobre todo inútil, oponer resistencia: "Se veía [Clara] desde afuera, porque en cierto modo había quedado afuera de sí misma. Le parecía, en efecto, que no dependía de su arbitrio, sino de otro, más grande, que mandaba en aquel salón, desde el cielo. A Gauna, a Valerga [...] a todos los habían sustraído de sus voluntades" (172).

El destino se revela, pues, en una serie de acciones que aparecen como independientes de la voluntad de los personajes, y en las cuales va urdiéndose, inexorable, la catástrofe: las dos apuestas ganadas en las carreras, la ausencia de Larsen, la sonrisa de Clara al Rubio que despierta los celos de Gauna y lo impulsa a alojarse junto al grupo.

Pero a esta primera definición se superpone, ya desde el inicio, otra: la del destino visto como búsqueda obstinada de una imagen de sí escogida sin alternativa. Con esto, después de todo, basta para desencadenar la aparente fatalidad. Taboada advierte con claridad a Gauna -y al lector- de esta segunda posibilidad: "Tu destino ha cambiado. Hace dos años estabas en pleno proceso de convertirte en el doctor Valerga. Clara te salvó" (101).

El destino es, entonces, el resultado de las acciones del hombre. Solo que éstas no siempre dependen de una voluntad consciente y racional. El mismo Gauna lo presiente: "también sospechó que la culpa de todo la tendrían, de una manera oscura y profunda, actos que, en apariencia, no podían vincularse a la voluntad de Clara; por ejemplo, haber cantado el tango Adiós, muchachos; o haberse atado, a la mañana, el zapato izquierdo antes que el derecho" (70).

La responsabilidad aquí se atribuye -exorcizándola- a acciones que no pueden guardar una relación con ciertos efectos; pero en esa absurda lista se menciona como una de las causas de la desventura el haber cantado un tango. Ese tango -que, como ya hemos visto, proclama "contra el destino / nadie la talla"- es el vínculo metafórico de Gauna con su imagen. Paradójicamente, la responsabilidad de Gauna radica en haber cantado Adiós, muchachos: adhesión simbólica a los valores que el tango transmite, es decir, a los mitos del 
machismo, del coraje demostrado con el cuchillo. Valores que para Gauna se encarnan en el mundo de Valerga, de los muchachos del barrio. Por eso, en el duelo final, el objeto que Gauna encuentra -la muerte- es el que inconscientemente andaba buscando: "Supo [...] que retomaba por fin su destino y que su destino estaba cumpliéndose" (178).

La reiteración no es aquí mero artificio retórico intensificador; aquí se reflejan mutuamente los dos sentidos posibles del destino: éste "se cumple" -es voluntad impersonal-; pero antes de que ello ocurra, Gauna debe "retomarlo". Es Gauna quien, al buscar la confirmación de su ser en un acto de coraje, provoca la reversión temporal. El destino de Gauna no es, pues, otra cosa que su incapacidad para reaccionar frente a la necesidad de una imagen social, su pasividad frente al mito del coraje (y aquí es obligada la referencia a Borges). La fatalidad nace de haber asumido, como única imagen aceptable del ser, el mundo de los compadritos, de los cuchilleros de arrabal. La fatalidad nace de la imposibilidad de elegir para sí una imagen diferente de la impuesta por el hecho de pertenecer a una clase. Es éste el único destino contra el cual luchar, como inútilmente intenta Taboada con sus pobres libros, con sus reflexiones. Quien "sustrae de sus voluntades" a Valerga, y a Gauna, y a todos, es un fantasma: la función social.

\section{Los privilegios de narrador}

Esta presencia de la sociedad como destino de los personajes puede rastrearse también en otro nivel del texto: la voz que narra. El narrador se halla en el mismo plano que los personajes en lo que atañe al grado de veracidad de los hechos; como ellos, carece de un conocimiento total. Sin embargo, la diferencia existe, y se deduce del juicio irónico que aquél se permite sobre los hechos y sobre los personajes. El narrador los mira desde arriba no sólo porque ésa es su función canónica en la ficción literaria, sino también porque así se lo permite su clase. En efecto, una serie de indicios revela una diferencia de ubicación social que permite al narrador ostentar un 
aire de superioridad cultural sobre los pobres diablos de la historia: Gauna, Clara, y todos los restantes. La distancia se marca sobre todo en el lenguaje: de Valerga se destaca insistentemente la falta de pronunciación de la "b" en palabras como "observar", "objetar", etc., defecto que connota de inmediato la ignorancia del personaje; esto ocurre igualmente con ese "calor" en femenino que no deja lugar a dudas sobre la extracción social de las máscaras que el grupo encuentra por la calle: "Y yo, les juro, con la calor temí que me diera un sofocón -aseguró el joven” (135).

La escasa cultura de Gauna no merece más indulgencia de parte del narrador: "... una Historia de los girondinos (obra que Gauna respetaba mucho, porque heredó de sus padres, y cuya lectura, en más de una oportunidad, había iniciado)" (42).

Asimismo, los esfuerzos de Clara por formar parte del mundo del teatro son ridiculizados por el narrador, para no hablar de sus inquietudes científicas: “... en un tomo del Tesoro de la juventud que les prestó un señor que era dentista, conocieron, con espanto, los animales antediluvianos, en cuadros que suponían tomados del natural" (100).

La diferencia de Taboada respecto a los demás radica en que en su gabinete abundan los libros y se destacan las imágenes de algunos pensadores como Spencer y Confucio, pero todo esto se halla en medio de elementos decorativos (tal vez atribuibles a Clara) que el narrador connota como irremediablemente cursis:

... en una mesa rinconera se adivinaba el teléfono, adentro de una muñeca de trapo, que representaba una negra (hay gallinas, parecidas, que se usan de cubreteteras); sobre una cómoda moderna, de cedro, con manijas negras y brillosas, había una flor que era rosada cuando hacía buen tiempo y azul cuando iba a llover, una caja de caracoles y de nácar, con la inscripción Recuerdo de Mar del Plata. (95)

Así pues, el mundo de estos personajes aparece como extremadamente reducido. Gauna, el héroe de la aventura extraordinaria, ve a los barqueros del lago de Palermo como lobos de mar sólo 
porque llevan tricota y pantalón azul; si expresa deseos de evasión, el máximo de exotismo que llega a imaginar es una provincia limítrofe.

Por otra parte, si se tiene en cuenta la fecha de publicación del libro (1954), su redacción puede ubicarse en la época del peronismo. En este contexto (y prescindiendo de la colocación de la historia en el período 1927-1930), ciertas afirmaciones cándidas y presuntuosas de los personajes resultan descifrables como distorsiones irónicas de algunas premisas peronistas en el campo político-cultural. En los discursos del crítico teatral en ciernes Baumgarten resuena, ridiculizado, un eco del proteccionismo cultural de Perón:

-Quisiera exponerle en términos palpables el problema de nuestro teatro. El autor nuevo, joven, argentino, se ahoga, se asfixia, sin contar con la posibilidad de ver corporizada su fantasía [...]. ¿Quién va a representarlo? Habría que bajar el cogote de las compañías, aunque más no fuera con la amenaza de la policía montada. Mientras el autor oscuro, imperfecto si se quiere, languidece en la lucha y no logra dar a luz sus engendros, el ventrudo público, ese dios burgués que inventó el liberalismo francmasón [...] pasa revista a las obras que se le antoja, eligiéndolas, porque no es un marmota, entre lo mejorcito del repertorio internacional. (58)

Gauna propone, con gran satisfacción de parte del grupo, un proyecto análogo en el plano económico: “-Si yo fuera gobierno -comunicó Gauna- no dejaría entrar un solo automóvil en el país. Con el tiempo se reproducirían de industria argentina y por enteramente asquerosos que fueran el público consumidor los compraría sin chistar, abonando un precio considerable" (80).

Los personajes se mueven, pues, en un horizonte cultural y político que el narrador, implícitamente o de modo explícito, caracteriza como limitado y negativo, merecedor, en el mejor de los casos, de un juicio irónico. Esa ironía encuentra una atenuación debido a la conciencia, de parte del narrador, de que es imposible, para los personajes, escapar a sus condicionamientos. 


\section{Un héroe sin derecho a sueños}

Esa conciencia, sin embargo, es lo que falta a los personajes. Falta porque, desde la perspectiva del narrador, aparece como un efecto de la cultura. Así, a Gauna le está vedado saber que un vínculo sutil une el café del barrio, Los Argonautas, donde el grupo acostumbra reunirse y donde él ha dado cita a Clara, al juicio de Taboada sobre su viaje maravilloso ("Hizo una especie de viaje. Ahora está añorando, como Ulises de vuelta en Itaca, o como Jasón recordando las manzanas de oro", 36) y al sueño que le anuncia la muerte. No puede saberlo porque, para quien carece de los instrumentos apropiados, toda iluminación es irreconocible. El destino de Gauna tiene origen en su incapacidad de acceso a su mundo interior. El sueño que da título a la novela, contado según el punto de vista y el lenguaje de Gauna, es la desolada comprobación de este límite:

Soñó que llegaba a un salón, iluminado con velas, donde había una mesa redonda, muy grande, a la que estaban sentados los héroes, jugando a la baraja. No se encontraban allí ni Falucho, ni el sargento Cabral, ni nadie que Gauna pudiera identificar. Había unos mozos medio desnudos, no salvajes, tan blancos de cara y de cuerpo que parecían de yeso; le recordaban el Discóbolo, una estatua que hay en el club Platense. Jugaban a la baraja con naipes de tamaño doble y -otra circunstancia notable- de esos que tienen tréboles y corazones. (159)

Estos 'héroes' son definidos como tales por alguien que no es Gauna, puesto que, para él, 'héroes' son los personajes de la historia americana que se estudian en la escuela. Tampoco las cartas en las que se juega el destino pertenecen al mundo de Gauna: él ni siquiera sabe cómo se llaman. Si puede nombrar al Discóbolo, tomado como parangón de aquellos hombres desnudos, es sólo porque se trata de una estatua que adorna su club. Es aquí donde la ironía de clase del narrador puede ejercitarse absoluta. El subconsciente del personaje juega con símbolos que no pertenecen al personaje mismo, y de nada puede servir que alguien explique a Gauna, 
al despertar, que las estatuas que lo rodean y que él ha soñado antes de verlas en la realidad son "Jasón y los héroes que lo acompañaron en sus aventuras" (159).

La posición del narrador va adquiriendo en esta perspectiva un significado ulterior: el de imagen transpuesta de la fatalidad. En su elección de un punto de vista limitado, el narrador se mimetiza con el mundo de los personajes, pero no puede evitar distinguirse, alejarse de ellos con los medios que le proporciona su cultura, es decir su clase. Después de todo, es la diferencia de clases lo que le permite contar la historia en los términos en que la cuenta. El mundo se encuentra así dividido entre aquéllos que sufren una condición y aquéllos que poseen los instrumentos para enunciarla. Poseer el poder de narrar significa, más simplemente, poseer el poder. No resulta entonces del todo inocente que sea este narrador quien dé nombre a la narración, quien elija el sentido de la aventura de Gauna, quien proponga con insistencia al lector una clave fantástica.

A punto de morir en el duelo, Gauna siente que ha encontrado la explicación de su sueño: "Se encontró de nuevo en el sueño de los héroes, que inició la noche anterior, en el corralón del rengo Araujo. Comprendió para quién estaba tendido el camino de alfombra roja y avanzó resueltamente" (178).

Pero esa alfombra roja, para ser identificada, ha sido comparada, en el mismo sueño, con la que había, "según es fama, en el Royal" (159). Podría, pues, parecer como la vía simbólica hacia algo diferente, que Gauna conoce sólo de oídas -de fama- o por referentes degradados, como el Discóbolo del club. Pero nadie puede abrir vías para Gauna, sino él mismo, y él es incapaz de hacerlo: ha aceptado su condición sin protestar, hasta con orgullo, creyendo escoger su propio destino cuando no ha hecho otra cosa que desempeñar el único oficio que le haya sido concedido, el de guapo. Y es éste el engaño supremo, que el narrador desplaza a la categoría de lo fantástico.

No entendemos, con lo anterior, limitar la posibilidad de una lectura fantástica de El sueño de los héroes. La segunda acepción del destino, como constricción social, privilegiada a lo largo de este análisis, no invalida la primera, es decir la de fatalidad sobrehumana. 
Ambas aparecen caracterizadas con un margen de ambigüedad que permite su coexistencia. Y es por esto que en el narrador se advierte también cierto respeto maravillado hacia sus personajes, heroicos a despecho de sí mismos, enfrentados a algo que rebasa su comprensión, pero también la del narrador. Ver El sueño de los héroes como una turbia epopeya de guapos de barrio no cancela los fulgores fantásticos de la novela, más bien la proyecta hacia otros planos de significación -que tampoco la agotan-, y demuestra que lo fantástico no es por naturaleza evasivo, sino que constituye -puede constituir- una de las formas críticas de lo real.

\section{Obra citada}

Bioy Casares, Adolfo. El sueño de los héroes. Madrid: Alianza Editorial, 1976. 